\title{
https://doi.org/10.46813/2021-133-111 \\ ANALYSIS OF RADIATION PROTECTIVE PROPERTIES OF POLYSTYRENE-BASED COMPOSITE MATERIALS
}

\author{
E.M. Prokhorenko ${ }^{1}$, V.V. Lytvynenko ${ }^{1}$, A.A. Zakharchenko ${ }^{2}$, M.A. Khazhmuradov', \\ S.A. Sokolov', T.G. Prokhorenko ${ }^{3}$, A.P. Ben ${ }^{4}$ \\ ${ }^{1}$ Institute of Electrophysics and Radiation Technologies NAS of Ukraine, Kharkiv, Ukraine; \\ ${ }^{2}$ National Science Center "Kharkov Institute of Physics and Technology”, Kharkiv, Ukraine; \\ ${ }^{3}$ Kharkov National Automobile and Highway University, Kharkiv, Ukraine; \\ ${ }^{4}$ Kherson State Maritime Academy, Kherson, Ukraine \\ E-mail:forshad58@gmail.com
}

Polystyrene-metal composite materials were manufactured. Composite materials are made of polystyrene, which has been reinforced with highly dispersed powder-like aluminum. Tungsten or steel powder was applied as a radiation shielding additive. The radiation-protective characteristics of composite materials were studied using sources of ionizing radiation ${ }^{241} \mathrm{Am}$ and ${ }^{152} \mathrm{Eu}$. Calculations of the relative attenuation of the absorbed dose of gamma radiation for protective materials with different mass composition have been performed. A comparison of the protective characteristics obtained experimentally and found by numerical methods is carried out. Hardness values were measured for composites with different component compositions. An increase in hardness with an increase in the amount of a metal component is shown.

PACS: 81.05.Qk, 87.55K-, 87.55N, 61, 80.Fe, 81.40.Wx

\section{INTRODUCTION}

Radiation protection is an important component in exploitation of nuclear objects and different equipment where sources of ionizing radiation are used [1 - 4]. The reasons for the close attention to the problem of improving radiation safety are legislative toughening to the norms of protection. The importance of the problem is evidenced by the attention to this issue of various nongovernmental and private organizations. This is due to the growth of amount of nuclear objects. The sources of ionizing radiation are more widely used on a production. The total number of radiation technologies in medicine is increasing. The approach to the storage and disposal of spent nuclear fuel and nuclear waste is changing [5]. The amount of depositories of exhaust nuclear fuel is increased, nuclear wastes. Also the question of utilization of different equipment which is a radiant costs sharply. The depositories of exhaust nuclear fuel are exploited long time. There is an accumulation of different devices and devices with sources of ionizing radiation. Many of these devices are nearing the end of their useful life. Consequently, the problem of radiation protection from ionizing radiation is topical and actual.

\section{PURPOSE OF WORK}

The main goal of the work is the development and improvement of polymer - metal composite materials. Experimental study of changes in the radiationprotective characteristics of composite materials. Comparison of the effectiveness of protection against ionizing radiation for materials with different component composition

\section{THE MAIN PART}

The effectiveness of radiation protection is determined by the effectiveness of the protective materials. At present, a huge number of different radiationprotective materials have been developed and used. However, interest in new materials is only growing.
This is due to the specifics of their application. All shielding materials are oriented on protection against various types of ionizing radiation and on protection against particles. To increase the effectiveness of radiation protection, it is possible to use composite materials. Therefore, the creation of new protective materials is a perspective direction. Modern science, technique and technology allow the creation of new radiation protective materials. The radiation-protective characteristics of these materials are higher. One of the directions is the development and creation of composite materials.

They consist of a bonding base and a radiation protection component. Complex structures are currently being developed. The development of composite materials is carried out for a specific task. Depending on the necessary requirements, the selection of the components of the composite material is carried out. Combining components with different properties makes it possible to obtain a material with new properties or improved basic characteristics.

In our case, we used the technique of structuring the binding base with a filler. After that, a component of a material with high radiation-protective properties was introduced into this composition. The component of the material had high dispersion. It is known that the use of particles of radiation-protective materials with nano sizes can increase the neutron absorption coefficient by 1.5 times, and the scattering coefficient of gamma radiation by $30 . .40 \%[2,3,6]$.

Polymers were used to create the bonding base. We can distinguish polymers that have increased plasticity, significant corrosion resistance, and low mass. These properties make it possible to operate composite materials at high pressure, in a wide temperature range, in aggressive environments.

Polystyrene PSM-115 (GOST 20282-86) was used as a bonding base. His temperature of melting $196 \ldots 200^{\circ} \mathrm{C}$. Temperature of softening $-86 \ldots 92^{\circ} \mathrm{C}$. At typical shielding thicknesses, only gamma quanta with 
energies up to $40 \mathrm{keV}$ are effectively absorbed. With an increase in the energy of gamma quanta (up to $1.5 \mathrm{MeV}$ ), the attenuation of the absorbed dose does not exceed $10 \%$. In order to increase the protective properties of composite materials, additives from radiationprotective materials are introduced into them. Heavy metals $(\mathrm{Pb}, \mathrm{W}, \mathrm{Mo})$ are used to protect against $\mathrm{X}$-ray and gamma radiation. Light elements $(\mathrm{B}, \mathrm{H}, \mathrm{N}, \mathrm{C}, \mathrm{Bi})$ are used to protect against streams of neutrons.

The choice, as the basis of polystyrene, is due to several of its properties. Among them: a) simplicity of manufacturing and processing of samples, b) it is possible to obtain samples of complex shape, c) technology of production of products from polystyrene is available. Also, polymers have an important property. Under the influence of ionizing radiation, two processes are possible in them. The first is the process of destruction (embrittlement, swelling, etc.). The second is the recovery process. It occurs due to the presence of individual chains of the phenolic radical in polystyrene macromolecules. This radical, under the influence of ionizing radiation, cooperates with similar radicals. As a result of this reaction, crosslinking of polymer chains occurs. Also, polystyrene wets some metals well. This also influenced the choice of polystyrene as the bonding base of the composite. It should be taken into account the fact that the manufacture of products from polystyrene has a low cost and is quite simple in production and processing.

The composite material, which consists of polystyrene and heavy metal components, has low durability and easily crumbles. This is due to the low connection between polystyrene elements and heavy metal particles. In order to reduce the destruction processes, the base is reinforced with various additives. Powdered aluminum was used to create a metal matrix (frame). In our case, we used powder aluminum ASD-6, 6111, 2014 (TU 1791-007-49421776-2011, ISO 209-1) or ASD-6 (TU 1791-007-49421776-2011, ISO 209-1) [7]. The aluminum powder forms a matrix that substantially strengthens the composite.

All this happens because powdered aluminum has a high surface chemical activity and is well wetted by polystyrene. When they interact, the maximum bond between individual particles of aluminum powder and polystyrene is achieved. Consequently, a composite consisting of polystyrene and aluminum has rather high strength characteristics.

The use of aluminum is justified by several more of its properties. Aluminum is a highly technological material. It is easy to press, amenable to processing, and has a high, well-known thermal conductivity. All this makes it possible to produce composite materials with a given shape.

In accordance with the Specifications, aluminum particles could have the following sizes: $10 \ldots 20$, $30 \ldots 40,60 \ldots 90 \mu \mathrm{m}$.

Powdered tungsten (PV-2 (TU 14-22-143-2000) PV-2 (TU 14-22-143-2000)) was used as a radioprotective component of the composite material. In accordance with the Technical Specifications, the particles of powder tungsten could have the following sizes: $20 \ldots 40$, $50 \ldots 60,120 \ldots 150,180 \ldots 210,230 \ldots 280 \mu \mathrm{m}$.
Powdered iron A182 (GOST 5950-2000), A57036 (GOST 977-75) [8 - 11] was also used as a radiationprotective additive. The sizes of individual grains are 230 or $380 \mu \mathrm{m}$. Note that the radiation-protective characteristics of iron are significantly lower than that of tungsten. However, the cost of powder iron became much cheaper than tungsten.

A wide range of particle sizes allows you to select the necessary grains. This is due to the fact that the characteristics of protection against ionizing radiation are significantly influenced by the physical dimensions of the filler particles, their spatial orientation in the bulk of the composite material, and the uniformity of distribution over the composite.

Thus, by selecting a binding material, a material for creating a volume matrix, and a radiation-protective component, we can obtain certain characteristics of a radiation-protective composite.

The creation of composites is associated with significant technological and production difficulties. Therefore, work on the creation of radiation-protective composite materials with predetermined characteristics and properties are a complex and nontrivial problem.

\section{CONDUCTING EXPERIMENTS AND DISCUSSION OF RESULTS}

Improvement of equipment. In the manufacture of composite materials, standard industrial equipment was used. Kuasy 100/25 and Windsor SP 80 machines were used to test the manufacturing technologies and obtain trial batches of the composite. The equipment was chosen due to the fact that it can produce products from reinforced polystyrene.

The production of composite materials is carried out by the extrusion method. The raw material is heated and the prepared melt is extruded into molds. These devices are horizontal hydraulic injection molding machines. They differ in the shape of the feeding augers, the volume of the working fluid and the force of the auger.

The Windsor SP 80 has an injection pressure of $30.000 \mathrm{~kg}$, and an injection volume of $187 \mathrm{~cm}^{3}$. The Kuasy 100/25-1 apparatus had an injection pressure of $180 \mathrm{MPa}$, an injection volume of $50 \mathrm{~cm}^{3}$.

For Kuasy 100/25-1, Windsor SP 80 devices, technological processes for the production of various complex shape products from polystyrene have already been developed and certified. We need it. However, these technological developments are insufficient. We need to make products that consist of three components. In this case, the two components are finely dispersed metal powder. Each of the components has its own particle size, its own particle weight. They differ in the values of heat capacity and thermal conductivity. Also, they are wetted in different ways with polystyrene. All these differences significantly complicate the process of manufacturing radiation-protective composite material.

We need to obtain a composite material with the maximum degree of homogeneity of the distribution of components over its volume. Therefore, the task of obtaining a composite material is difficult. When solving this problem, a lot of work was done to improve the Kuasy 100/25-1 and Windsor SP 80 devices [12]. Additionally, a heating system was installed in the thermo- 
plastic apparatus. This system made it possible to preheat a mixture of components. Also, the thermoplastic apparatus was supplemented with a device for mixing the mixture of components. This increased the degree of homogeneity of the mixture. Both the auxiliary heating system and the mixing system had separate devices for adjusting their operation. This made it possible to obtain a uniform distribution of components throughout the volume of the composite material.

In the process of extrusion of the prepared mixture, further shear deformation of the particles occurs relative to each other in the polystyrene melt. This leads to an even more uniform distribution of particles in the composite material. Also, in the casting process, topochemical reactions occur between polystyrene and aluminum. At the same time, a strong bond is formed between the components of the composite, which gives increased characteristics of the density and strength of the composite material.

It should be noted that the homogeneity of the mixture heating has a great influence on the homogeneity of the distribution of the components. This is due to the fact that different components of the composite material have different characteristics and properties. So tungsten is significantly heavier than polystyrene and aluminum. Tungsten and aluminum have different sizes. They have very different thermal conductivities and heat capacities. All this together complicates the process of heating and the mixing process of the components. The deviation of the temperature of the mixture from the melting point, or deviation from the mixing mode, changes the distribution of the components over the volume of the composite. The appearance of granules, lumps is possible. These inhomogeneities reduce the strength of the composite material, change its structure and density.

There is also a problem with the stratification of metal components in the volume of the composite. This heterogeneity worsens the radiation-protective characteristics.

To control the heating process, an IR radiometric technique has been proposed and put into practice. For this purpose, thermal imaging devices Lend Ti-814, Fluke-10, Fluke-25 were used [13]. The sensitivity of these devices was in the temperature range from 0.5 to $0.08^{\circ} \mathrm{C}$. To carry out our work, this temperature measurement accuracy is sufficient.

Preparation of samples. For the leadthrough of stand tests four samples were made. Their original appearance is shown in Fig. 1.

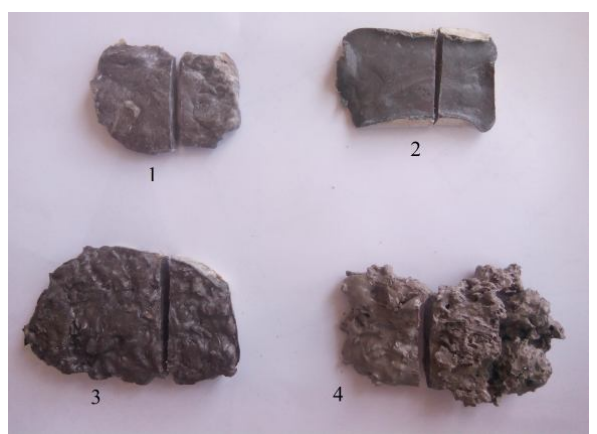

Fig. 1. Original appearance of samples with different component composition
The sizes of the samples of composite materials are $70 \times 40 \times 15 \mathrm{~mm}$.

All samples had different densities and different filling. Sample № 1 consisted of polystyrene reinforced with finely dispersed aluminum powder. Particle size of aluminum is $10 \ldots 20 \mu \mathrm{m}$.

Tungsten with a particle size of $50 \ldots 60 \mu \mathrm{m}$ was used as a radiation shielding component. For samples № 2, 3, 4, iron powder was used instead of tungsten. The particles of powder of iron had a size $230 \mu \mathrm{m}$ (samples № 2, 4), and 380 m (sample № 3).

The sizes of samples were more than it is necessary for measurings. From every presented sample a fragment, suitable for placing in a stand, was dissociated. Samples cut across. On Fig. 1 places are visible, where transverse sections are executed. The fragments of sample have twice less sizes

On the structure of surface of cuts differ insignificantly. An enlarged image of surfaces is shown in Fig. 2.

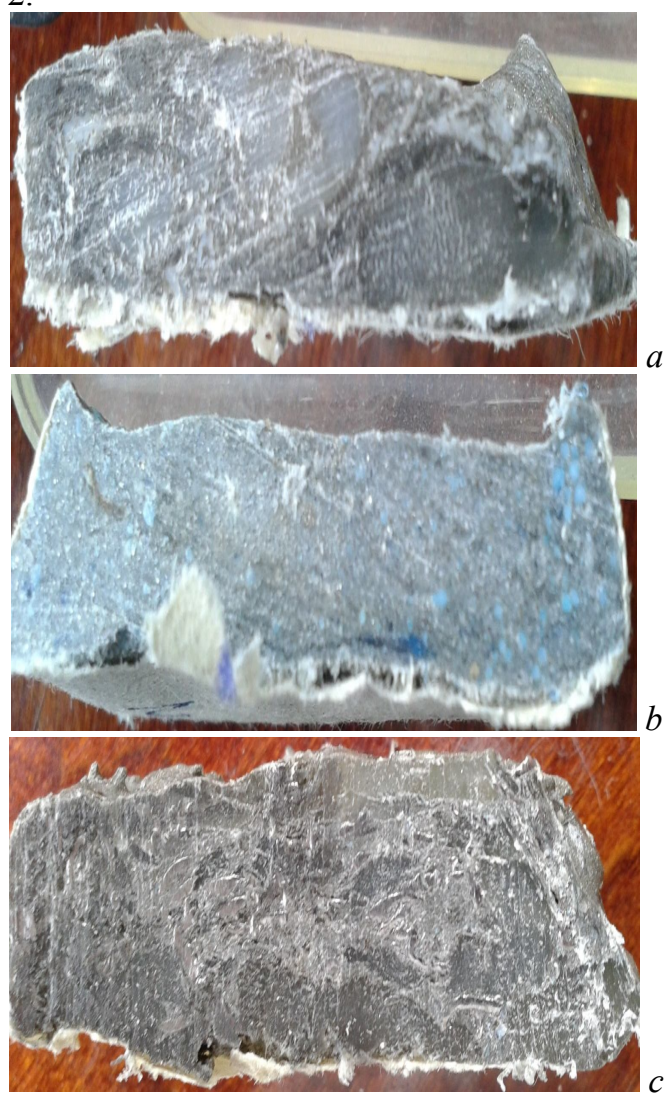

Fig. 2. Original appearance of the cut surface: first sample (a); second sample (b); third sample (c)

Sample № 1 had the smoothest surface of cut of. On the surface of the section of sample № 2, we observe slight roughness. The cut surface of sample № 3 most rough. The reason for this in a sample № 1 size of particle of tungsten is $50 \ldots 60 \mu \mathrm{m}$. In sample № 2, iron particles were $230 \mu \mathrm{m}$ in size. In sample № 3, iron particles had the maximum size $(380 \mu \mathrm{m})$.

Two sources of radiation, ${ }^{241} \mathrm{Am}$ and ${ }^{152} \mathrm{Eu}$, were used for research. All measurements were carried out by the "Amptek" spectrometric channel, which consists of a preamplifier with an "XR100T" detector and a "PX5" microprocessor signal processing unit $[14,2]$. The geometry of the location of the samples in relation to the 
sources is shown in Table 1. Also in Table 1, the thick ness of the samples is given.

Table 1

Geometry of irradiation of samples

\begin{tabular}{|c|c|c|c|}
\hline $\begin{array}{c}\text { Sample, } \\
\text { № }\end{array}$ & $\begin{array}{c}\text { Distance } \\
\text { from sample } \\
\text { to source, } \\
\mathrm{mm}\end{array}$ & $\begin{array}{c}\text { Distance } \\
\text { from sample } \\
\text { to detector } \\
\text { housing, } \mathrm{mm}\end{array}$ & $\begin{array}{c}\text { Sample } \\
\text { thickness, } \\
\mathrm{mm}\end{array}$ \\
\hline 1 & 16.83 & 1.5 & 8.07 \\
\hline 2 & 15.76 & 1.5 & 7.58 \\
\hline 3 & 8.30 & 1.5 & 16.65 \\
\hline 4 & 7.95 & 1.5 & 15.08 \\
\hline
\end{tabular}

To determine the density $(\rho)$, hydrostatic weighing was performed. Initially, the mass $(m)$ of the composite material sample was found in air. Then the mass $\left(m_{l}\right)$ of the composite sample was found in distilled water. The density was determined of expression (1):

$$
\rho=\rho_{w} \cdot \frac{m}{m-m_{1}} .
$$

In expression (1) $\rho_{W}$ is the density of distilled water. It has the value $\rho_{W}=0.998 \mathrm{~g} / \mathrm{cm}^{3}$.

The density of the samples, measured by hydrostatic weighing (based on Archimedes' law), is given in Table 2 .

Table 2

\begin{tabular}{|c|c|}
\multicolumn{2}{|c|}{ Density of samples } \\
\hline $\begin{array}{c}\text { Sample, } \\
\text { № }\end{array}$ & $\begin{array}{c}\text { Density, } \\
\mathrm{g} / \mathrm{cm}^{3}\end{array}$ \\
\hline 1 & 1.11 \\
\hline 2 & 1.16 \\
\hline 3 & 1.75 \\
\hline 4 & 1.31 \\
\hline
\end{tabular}

The samples were made with a small amount of a component that reinforces the composite (aluminum) and the radiation-shielding component (tungsten or iron).

Since components in the form of powder are mixed in the production of a composite material, it is best to calculate for parts with different volumes. Composition of composition materials on volume is resulted in Table 3 .

Table 3

Sample composition (volume distributing)

\begin{tabular}{|c|c|}
\hline $\begin{array}{c}\text { Sample, } \\
\text { № }\end{array}$ & $\begin{array}{c}\text { Composition } \\
\text { (PS: Me: } \mathrm{Al})\end{array}$ \\
\hline 1 & $14.95: 0.005: 0.045$ \\
\hline 2 & $14.8: 0.1: 0.1$ \\
\hline 3 & $12.7: 1.3: 1$ \\
\hline 4 & $13.78: 0.22: 1$ \\
\hline
\end{tabular}

A 15-part system was used to make the composite samples. This is due to the fact that the loading box of the thermoplastic device of the apparatus contained 15 measuring containers. Therefore, the table shows the volumes in parts of the measuring container.

Information on the mass composition of composite material samples is interesting. It allows you to assess the need for raw materials in the manufacture of com- posite materials. The composition of the samples of composite materials by weight is given in Table 4 .

Table 4

Mass composition of samples (wt.\%)

\begin{tabular}{|c|c|c|c|}
\hline $\begin{array}{l}\text { Sample, } \\
\text { № }\end{array}$ & \multicolumn{3}{|c|}{$\begin{array}{l}\text { Composition } \\
\text { (PS: Me: Al) }\end{array}$} \\
\hline & $\mathrm{PS}(\%)$ & $\mathrm{W}(\%)$ & $\mathrm{Al}(\%)$ \\
\hline 1 & 98.692 & 0.579 & 0.729 \\
\hline & & $\mathrm{Fe}(\%)$ & \\
\hline 2 & 93.9 & 4.53 & 1.56 \\
\hline 3 & 53.72 & 35.98 & 10.30 \\
\hline 4 & 77.39 & 8.83 & 13.78 \\
\hline
\end{tabular}

Samples were made with the addition of small amounts of metal components. This was done to simplify the process of comparing experimental results with the results of theoretical calculations [15 - 17].

Initially, the study of the radiation-protective characteristics of composite materials was carried out on the ${ }^{241} \mathrm{Am}$ source. The change in the photopeak of $59.54 \mathrm{keV}$ was studied for the samples that were studied. Its graph is shown in Fig. 3.

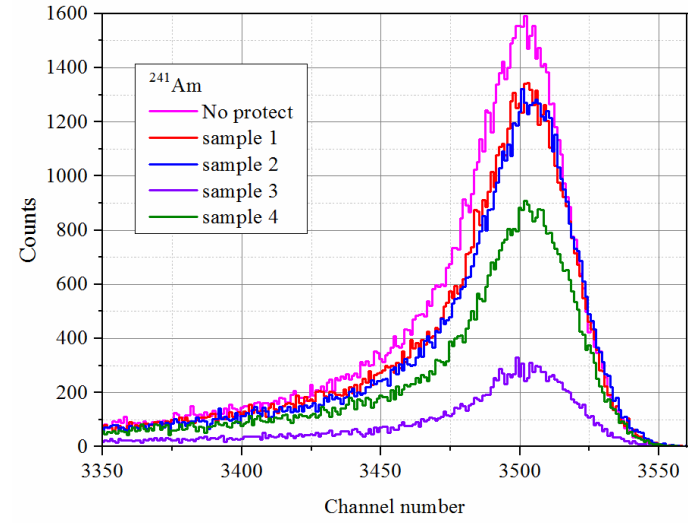

Fig. 3. Graph of the $59.54 \mathrm{keV}$ photopeak of the ${ }^{241}$ Am source

The graph shows a change in the shape of the $59.54 \mathrm{keV}$ photopeak of the ${ }^{241} \mathrm{Am}$ source, which depended on the type of composite material. Pure polystyrene has minimal protective properties. The graph of the photo peak is shown with a pink curve. Samples № 1 (red curve) and №2 (blue curve) have similar radiation protection parameters. Sample № 1 had a low content of tungsten and aluminum components. Sample № 2 consisted of iron and aluminum components. The amount of aluminum powder in sample № 2 is twice as much as in sample № 1. The amount of iron powder is nine times greater than that of tungsten powder. However, due to the lower radiation-protective properties of iron, the protective characteristics of the samples are similar.

With an increase in the amount of the metal component, the protective characteristics of the composite material increase. This dependence is displayed by the graphs of samples № 3 and 4. The green curve corresponds to the protective properties of sample № 4. In sample № 4, the amount of the iron component (by weight) is twice as high as in sample № 2. Aluminum powder in two times anymore. 
Sample № 3 (violet curve) has the maximum radiation-protective properties. The amount of iron powder is $36 \%$. The total mass of the metal component is $47 \%$.

To compare the protective characteristics, we additionally measured polystyrene with a density of $0.98 \mathrm{~g} / \mathrm{cm}^{3}$. The absolute and relative values of area of photopeak of $59.54 \mathrm{keV}$ are presented in Table 5 .

Table 5

Measured and relative values of area of photopeak of $59.54 \mathrm{keV}$

\begin{tabular}{|c|c|c|}
\hline Sample, № & $\begin{array}{c}\text { Measured } \\
\text { photopeak } \\
\text { area } \\
59.54 \mathrm{keV}\end{array}$ & $\begin{array}{c}\text { Relative meas- } \\
\text { ured area of the } \\
\text { photopeak } \\
59.54 \mathrm{keV}\end{array}$ \\
\hline Without sample & 85951.0 & 1 \\
\hline $\begin{array}{c}\text { PS } \\
0.98 \mathrm{~g} / \mathrm{cm}^{3}\end{array}$ & 72831.5 & 0.847 \\
\hline 1 & 72611.5 & 0.845 \\
\hline 2 & 69731.5 & 0.811 \\
\hline 3 & 16950.0 & 0.197 \\
\hline 4 & 49545.0 & 0.576 \\
\hline
\end{tabular}

Using mathematical methods $[18,19,20]$, the absolute and relative areas of the $59.54 \mathrm{keV}$ photopeak were calculated. The calculation results are presented in Table 6

Table 6

Relative values of area of фотопика of $59.54 \mathrm{keV}$

\begin{tabular}{|c|c|c|}
\hline Sample, № & $\begin{array}{c}\text { Relative meas- } \\
\text { ured area of the } \\
\text { photopeak } \\
59.54 \mathrm{keV}\end{array}$ & $\begin{array}{c}\text { Relative calcu- } \\
\text { lated area of the } \\
\text { photopeak } \\
59.54 \mathrm{keV}\end{array}$ \\
\hline Without sample & 1 & 1 \\
\hline $\begin{array}{c}\text { PS } \\
0.98 \mathrm{~g} / \mathrm{cm}^{3}\end{array}$ & 0.847 & 0.847 \\
\hline 1 & 0.845 & 0.845 \\
\hline 2 & 0.811 & 0.812 \\
\hline 3 & 0.197 & 0.196 \\
\hline 4 & 0.576 & 0.575 \\
\hline
\end{tabular}

The second column of Table 6 gives the measured photopeak area. The calculated area of фотопика is resulted in the third column of Table 6 . They are presented in the resulted kind. In calculations, the area of the photopeak without a sample was considered as the base one.

Comparison of measured results with calculated results was performed. The differences between them are minor. The values of sizes of the second and third columns differ in the third and fourth sign after a comma. These results show a high agreement between theoretical calculations and experimental results. The results were obtained in the case of the presence of a small amount of metal components in the composite material. Therefore, it is possible to replace the results of experimental studies the results of mathematical calculations. This avoids the leadthrough of bulky and costly experimental tests.

Experimental work was also carried out using a ${ }^{152} \mathrm{Eu}$ ionizing radiation source. The radiation from the source passed through the samples. A fragment of the emission spectrum from the ${ }^{152} \mathrm{Eu}$ source is shown in Fig. 4.

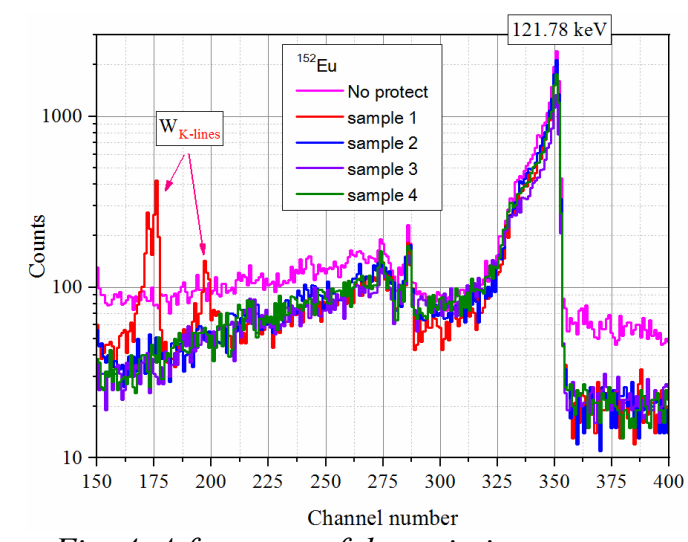

Fig. 4. A fragment of the emission spectrum of the ${ }^{152} \mathrm{Eu}$ source for the studied samples

To determine the effectiveness of the radiationprotective properties of the samples of composite materials, we studied the emission spectrum from the ${ }^{152} \mathrm{Eu}$ source. The presence of tungsten in the sample № 1 is confirmed. This is evidenced by the K-line peaks in the energy range $60 \ldots 70 \mathrm{keV}$. For iron-containing samples № (2-4), similar peaks were not observed. The peak values of $121.78 \mathrm{keV}$ also coincide with the calculated values. When comparing other experimental data with theoretical calculations, we also observe their good agreement.

Calculation of radiation-protective characteristics. Exact knowledge of the radiation-protective characteristics of composite materials is necessary for their practical application. However, the experimental measurement of the protective properties of composite materials is a laborious task. Therefore, the results of theoretical calculations are used.

The work showed a high agreement between theoretical calculations and experimental measurements. Several packages have been developed for theoretical calculations of protective properties. In our calculations, we used the Geant4 v 4.9.6p03 package [18, 19]. In these calculations, the effect of ionizing radiation on a biological phantom was considered. The basic parameter of efficiency of protection is the relative attenuation of dose of ionizing radiation. This parameter is calculated on a mathematical formula:

$$
\eta=1-\frac{D}{D_{\text {air }}},
$$

$D_{\text {air }}$ - is the calculated dose, in the absence of protection. $D-$ is the calculated dose when protected. $\eta-$ is the degree of relative attenuation of the absorbed dose of gamma radiation by a layer of protection made of a composite material.

The curves of the relative weakening of doses were calculated. They are found for the case of an ideal composite material. That is, the material was homogeneous in density throughout the entire volume. The charts of the relative weakening of doses are shown in Fig. 5.

The calculations were carried out for composite materials with different amounts of polystyrene, aluminum, and a radiation-protective component (tungsten or iron). The composite material was in the form of spheres with a diameter of $1 \mathrm{~cm}$. This shape allowed it to be freeflowing. The form was determined by the previously put 
forward requirements. By volumetric composition, composite materials were divided into three groups.

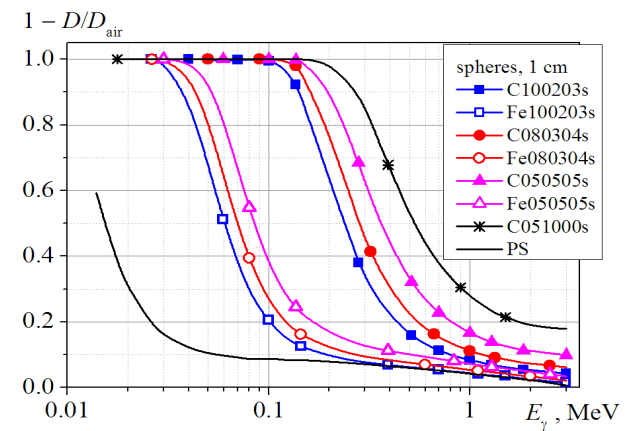

Fig. 5. Graph of changes in the relative attenuation of the absorbed dose from the energy of gamma radiation

The composites in the group differed in the type of radiation-protective additive. In each group, one composite has a tungsten additive. Another composite has the same amount of iron additive. In Fig. 5, we observe two groups of curves. One corresponds to composites in which the addition of tungsten powder was used (indicated by filled-in markers).

The second group of curves are composites with a component of iron powder (indicated by markers with an empty middle). Composite materials with the addition of a tungsten component make it possible to obtain maximum attenuation of ionizing radiation. Composite materials using iron powder have lower radiationshielding characteristics. Therefore, their area of application is more specific.

Measurement of hardness of samples. The strength of composite materials allows you to assess their suitability for their specific tasks. Based on this parameter, we can calculate the optimal dimensions of radiation protective structures, determine the time of their operation. The strength characteristic is a generalized parameter. It is closely related to the concept of hardness

Hardness for polystyrene-metal composites includes a) the hardness of the surface coating; b) the hardness of the surface; c) the hardness of the material itself. In this case, hardness is associated with certain properties of composite materials. This is the resistance of a composite material to permanent deformation. The resistance to pressure during operation depends on hardness.

Hardness is determined by the resistance of a material to penetration deep into the material. A number of other characteristics of composite materials also depend on hardness.

For determination of hardness of полистиролметаллических composition materials different methods are used. For the case of the reinforced composition materials apply the methods of Shora (Shore (scales of A, D)) [ISO 868, DIN 53505, ASTMD2240], Barkola [ASTM B648-2000, ASTM D-2583], Rockwell (HR (scale P)) [GOST 9013, GOST 24622, ISO 2039/2].

They use indenters of various configurations. These indenters are introduced in the volume of the composite material. The hardness is determined from the resistance of the material to the penetration of the indenter into it. For Shor's and Barcol's methods, the depth of penetration of the indenter into the material is measured. In measurements, pointed indenters are used, which are close to a needle in shape.

In the Rockwell hardness measurement method, the indenter is a tungsten carbidic ball with a diameter of $12.7 \mathrm{~mm}$. The ball is pressed into the material.

The calculation of hardness is executed by the formula:

$$
H R=130-(H-h) / 0.002,
$$

$h$ - is the depth of penetration of the indenter (ball) under preload; $H$ - is the depth of penetration of the indenter (ball) under the main load.

When measuring the hardness of our composites, the Shore and Barcol methods have low efficiency. This is due to the fact that composite materials are reinforced with metal particles (aluminum, tungsten or iron). With a high filling of composite materials with a metal component, there is a high probability of the indenter getting into the metal particle. As a result, measurements will give inexact results. Therefore, it is necessary to carry out a large number of measurements. The most optimal method for measuring the hardness of composite materials reinforced with metal powder is the Rockwell method (HR (P)).

As an example, let's imagine the number of measurements required when different methods are applied. When obtaining results with variance: $D=1.55$ and standard deviation $\sigma=1.75$, it is necessary to make 1-2 measurements by the Rockwell method (HR (P)), 3-4 measurements by the Shore method (Shore (D, M)), 7 measurements by the Barcol method. When $D=1.05$ and standard deviation $\sigma=1.45$, you need to make 2-3 measurements using the HR (P) method, 6-8 measurements using the Shore $(\mathrm{D}, \mathrm{M})$ method, 12 measurements using Barcol method. For $D=0.358$ and standard deviation $\sigma=0.632-$ it is necessary to perform 4-5 measurements in HR $(\mathrm{P}), 8-10$ in Shore $(\mathrm{D}, \mathrm{M})$, 15-17 in Barcol method.

Consequently, when measuring the hardness of polystyrene-metal composite materials, the Rockwell method (HR (P)) is the most effective.

The disadvantage of this method is the conventionality of units of hardness. These units are not tied to physical quantities.

Conversion of these units into physical quantities is performed according to special nonlinear tables. Translation of these hardness values into physical values is possible only for certain materials.

For the measurements used the device NOVOTESTTP. His analogues are devices of TK-2, TSH-500, HR1500.

When measured by the Rockwell method, the hardness of the first sample was $80 \mathrm{HR}(\mathrm{P})$. This slightly exceeds the hardness of pure polystyrene $78 \mathrm{HR}(\mathrm{P}))$. The hardness of the second sample is $82 \mathrm{HR}(\mathrm{P})$. The hardness of the fourth sample is $87 \mathrm{HR}(\mathrm{P})$. The third sample had the maximum hardness of $88 \mathrm{HR}(\mathrm{P})$. The hardness of the third and fourth samples differs significantly from the hardness of the first and second samples. This is due to the large amount of aluminum and iron powders. The result is a better reinforcement of the composite material. 
Analysis of the hardness of samples № 3 and 4 reveals certain patterns. The hardness value differed by one. However, in sample № 3 there is five times more iron powder than in sample № 4. The amount of aluminum powder in the samples was equal. Consequently, the addition of aluminum has a decisive effect on the hardness of composite materials. And this is due to its stronger bonds with polystyrene. Also, aluminum had, in comparison with iron, smaller particle sizes. It allows more fully to fill the volume of the composite material.

Thus, it is possible to select the required composite material with radiation-protective and hardness characteristics that are required in each specific case.

\section{CONCLUSIONS}

1. Samples of composite materials intended for protection against ionizing radiation were made.

2. The efficiency of attenuation of gamma radiation from ${ }^{241} \mathrm{Am},{ }^{241} \mathrm{Am}$ and ${ }^{152} \mathrm{Eu},{ }^{152} \mathrm{Eu}$ sources after radiation passes through the samples has been experimentally investigated.

3. By numerical methods, the values of the attenuation of gamma radiation for the samples that have been manufactured have been found.

4. Comparison of the experimental findings and theoretical calculations is executed.

5. A method for measuring the hardness of composite materials has been selected. The Rockwell method was used to measure the hardness of samples of radiation-protective composite materials.

6 . It was determined that hardness rises with the increase of amount in the compo of metallic компоненты. It is found that the increase of hardness in direct ratio depends on the amount of particles of aluminum and their small size.

\section{REFERENCES}

1. Shruti Nambiar, John T.W. Yeow. Polymercomposite materials for radiation protection // ACS Appl. Mater. Interfaces. 2012, № 4, v. 11, p. 57175726.

2. E.M. Prohorenko, A.A. Zaharchenko, A.I. Scrypnyk, M.A. Hazhmuradov, V.F. Klepikov, V.V. Lytvynenko. Improving of characteristics of composite materials for radiation biological protection // Problems of Atomic Science and Technology. 2013, № 3 (85), p. 240-243.

3. P.V. Matyukhin. Theoretical preconditions of new kinds of nuclear protective metal composite materials development based on ferric and bismuth oxides capsulated into metallic aluminum matrix // International Journal of Applied and Fundamental Research. 2011, № 2, p. 42.

4. P.D. Bloom, K.G. Baikerikar, J.U. Otaigbe, V.V. Sheares. Development of novel polymer/quasicrystal composite materials // Mat. Sci. Eng. A-Struct. 2000, 294-296:156-159.

5. V.F. Klepikov, E.M. Prokhorenko, V.V. Lytvynenko, S.E. Donets, V.N. Robuk, T.G. Prokhorenko, V.T. Uvarov, A.G. Ponomarev, Yu.F. Lonin. The use of high-current relativistic electron beams for the study of the effects of ionizing radiation on materials storage RAW // Problems of Atomic Science and Technology. 2016, № 2 (102), p. 72-77.

6. K. Verdipoor, A. Alemi, A. Mesbahi. Photon mass attenuation coefficients of a silicon resin loaded with $\mathrm{WO}_{3}, \mathrm{PbO}$, and $\mathrm{Bi}_{2} \mathrm{O}_{3}$ Micro and Nano-particles for radiation shielding // Radiat. Phys. Chem. 2018, v. 147 , p. $85-90$.

7. V.V. Bryukhovetskiy, N.I. Bazaleev, V.F. Klepikov, V.V. Litvinenko,

O.E. Bryukhovetskay, E.M. Prokhorenko, V.T. Uvarov, A.G. Ponomar'ov. Features of gelation of surface of industrial aluminium alloy 6111 in the area of influence of impulsive bunch of electrons in the mode of premelting // Problems of Atomic Science and Technology. 2011, № 2 (72), p. 28-32.

8. E.M. Prokhorenko, V.F. Klepikov, V.V. Lytvynenko, P.A. Khaymovich, N.A. Shul'gin, A.I. Morozov. Diagnostics of processes of wear of materials of balls drum mills // Eastern European Journal of Enterprise Technologies. 2015, № 1/5, v. 73, p. 14-20.

9. V.I. Pavlenko, R.N. Yastrebinskii, P.V. Matyukhin, D.V. Voronov. Interaction of fast electrons and gamma-quanta with radiation protection ferric oxide composites // Russian Physics Journal. 2008. v. 51, № 11, p. 1188-1194.

10. E.M. Prokhorenko, V.V. Lytvynenko, O.A. Melyakova, Yu.F. Lonin, A.G. Ponomarev, V.T. Uvarov, N.A. Shul'gin, T.G. Prokhorenko, R.I. Starovoytov, A.I. Morozov, S.R. Artemev. Strengthening of the surface of steel (9XФM) exposed to a high-current electron beam // Problems of Atomic Science and Technology. 2020, № 1 (125), p. 28-32.

11. E.M. Prokhorenko, V.V. Lytvynenko, O.A. Melyakova, Yu.F. Lonin, A.G. Ponomarev, V.T. Uvarov, N.A. Shul'gin, T.G. Prokhorenko. Modification of structure of the surface of steel (ХГС) as result of influences of high-current electron beem // Problems of Atomic Science and Technology. 2020, № 2 (126), p. 47-53.

12. E.M. Prohorenko, V.V. Lytvynenko, A.A. Zaharchenko, M.A. Hazhmuradov, T.G. Prokhorenko. Studying the changes in the characteristics of radiationprotective composition materials in dependence on homogeneity of distributing of metal components // Problems of Atomic Science and Technology. 2019, № 2 (120), p. 121-126.

13. E.M. Prohorenko, V.F. Klepikov, V.V. Lytvynenko, N.I. Bazaleyev, I.I. Magda, T.G. Prohorenko, A.I. Morozov. Application of ir-radiometric diagnostics for control of vacuum connections of electrophysical installations // Problems of Atomic Science and Technology. 2018, № 1 (113), p. 212-217.

14. A.I. Scrypnyk, A.A. Zakharchenko, M.A. Khazhmuradov, E.M. Prokhorenko, V.F. Klepikov, V.V. Lytvynenko. Simulation of Characteristics of Gamma-Radiation Detectors Based on Mercury Compounds // Problems of Atomic Science and Technology. 2013, № 3 (85), p. 231-235.

15. V.F. Klepikov, E.M. Prokhorenko, V.V. Lytvynenko, A.A. Zaharchenko, M.A. Hazhmuradov. Control of macroscopic characteristics of composite materials for radiation protection // Problems of Atomic Science and Technology. 2015, № 2 (96), p. 193-196. 
16. E.M. Prokhorenko, V.F. Klepikov, V.V. Lytvynenko, A.A. Zaharchenko, M.A. Hazhmuradov. Metal containing composition materials for radiation protection // Problems of Atomic Science and Technology. 2014, № 4 (92), p. 125-129.

17. V.F. Klepikov, E.M. Prokhorenko, V.V. Lytvynenko, A.A. Zaharchenko, M.A. Hazhmuradov. Application of methods of mathematical modeling for determining of radiation-protective characteristics of polystyrene-metal composite materials // Problems of Atomic Science and Technology. 2016, № 3 (103), p. $123-127$.
18. S Agostinelli, J. Allison, K. Amako. Geant4 - a simulation toolkit // Nucl. Instr. and Meth. A. 2003, v. 506, p. 250-303.

19. J. Allison, K. Amako, J. Apostolakis, H. Araujo, et al. Geant4 developments and applications // IEEE Transactions on Nuclear Science. 2006, v. 53, p. 270-278.

20. V.F. Klepikov, E.M. Prokhorenko, V.V. Lytvynenko, A.A. Zaharchenko, M.A. Hazhmuradov. Performance ratio hardness characteristics polystyrene-metal composite materials // Problems of Atomic Science and Technology. 2015, № 5 (99), p. 36-42.

Article received 08.02 .2021

\title{
АНАЛИЗ РАДИАЦИОННО-ЗАЩИТНЫХ СВОЙСТВ КОМПОЗИЦИОННЫХ МАТЕРИАЛОВ НА ОСНОВЕ ПОЛИСТИРОЛА
}

\author{
Е.М. Прохоренко, В.В. Литвиненко, А.А. Захарченко, М.А. Хажмурадов, С.А. Соколов, \\ Т.Г. Прохоренко, А.П. Бень
}

Были изготовлены полистирол-металлические композиционные материалы, из полистирола, который был армирован высокодисперсным порошковым алюминием. Порошок вольфрама или стали применяли как радиационно-защитную добавку. Радиационно-защитные характеристики композиционных материалов исследовались при помощи источников ионизирующего излучения ${ }^{241} \mathrm{Am}{ }^{152} \mathrm{Eu}$. Выполнены расчеты относительного ослабление поглощенной дозы гамма-излучения для защитных материалов с различным массовым составом. Проведено сравнение защитных характеристик полученных экспериментально и найденных численными методами. Выполнялось измерение значений твердости для композитов с различным компонентным составом. Показано увеличение твердости при увеличении количества металлической компоненты.

\section{АНАЛІЗ РАДІАЦІЙНО-ЗАХИСНИХ ВЛАСТИВОСТЕЙ КОМПОЗИЦІЙНИХ МАТЕРІАЛІВ НА ОСНОВІ ПОЛІСТИРОЛУ}

\section{С.М. Прохоренко, В.В. Литвиненко, О.О. Захарченко, М.А. Хажмурадов, С.О. Соколов, Т.Г. Прохоренко, А.П. Бень}

Були виготовлені полістирол-металеві композиційні матеріали, виготовлені з полістиролу, який був армований високодисперсним порошковим алюмінієм. Порошок вольфраму або сталі застосовували як радіаційно-захисну добавку. Радіаційно-захисні характеристики композиційних матеріалів досліджувалися за допомогою джерел іонізуючого випромінювання ${ }^{241} \mathrm{Am} \mathrm{i}{ }^{152} \mathrm{Eu}$. Виконано розрахунки відносного ослаблення поглиненої дози гамма-випромінювання для захисних матеріалів із різним масовим складом. Проведено порівняння захисних характеристик отриманих експериментально і знайдених чисельними методами. Виконувався вимір значень твердості для композитів з різним компонентним складом. Показано збільшення твердості при збільшенні кількості металевої складової. 